\title{
Effects of invasive species snails in continental aquatic bodies of Pernambucano semiarid
}

\author{
Efeitos de espécies invasoras de moluscos gastrópodes em corpos aquáticos continentais
} do semiárido Pernambucano

\author{
Paulo Rogério de Souza Almeida ${ }^{1 *}$, Silvano Lima do Nascimento Filho \\ and Girlene Fábia Segundo Viana ${ }^{3}$
}

\begin{abstract}
${ }^{1}$ Programa de Pós-graduação em Recursos Pesqueiros e Aquicultura, Universidade Federal Rural de Pernambuco - UFRPE, Av. Dom Manoel de Medeiros, s/n, Dois Irmãos, CEP 52171-900, Recife, PE, Brasil

${ }^{2}$ Programa de Ecologia, Universidade Federal Rural de Pernambuco - UFRPE, Av. Dom Manoel de Medeiros, s/n, CEP 52171-900, Dois Irmãos, RE, Brasil

${ }^{3}$ Engenharia de Pesca da Unidade Acadêmica de Serra Talhada - UAST, Universidade Federal de Pernambuco - UFRPE, Av. Gregório Ferraz Nogueira, s/n, José Tomé de Souza Ramos,

CEP 56909-535, Serra Talhada, PE, Brasil

*e-mail: paulo.sralmeida@gmail.com
\end{abstract}

Cite as: Almeida, P.R.S., Nascimento Filho, S.L. and Viana, G.F.S. Effects of invasive species snails in continental aquatic bodies of Pernambucano semiarid. Acta Limnologica Brasiliensia, 2018, vol. 30, e103.

Abstract: Aim: The aim of this study was to survey the species of molluscs and to evaluate the effect of exotic species on the native mollusks of three reservoirs in the Pajeú Basin Cachoeira II, Jazigo and Serrinha. Methods: Sampling was carried out with trawl net $(5 \mathrm{~mm}$ mesh opening) and hand net $(2 \mathrm{~mm}$ mesh opening). Results and conclusions: Were quantified 60,244 specimens, distributed among the species Melanoides tuberculata (49,398), Pomacea lineata (573), Biomphalaria straminea (376) and Physa marmorata (01). The invasive exotic species $M$. tuberculata was dominant in all reservoirs with a relative abundance greater than $85 \%$ and the other species were classified as occasional and rare, with emphasis in Physa marmorata that is present in the red list of species vulnerable to extinction. Regarding the frequency of occurrence, all species were classified as euconstant (occurrence greater than $65 \%$ ), except $P$. lineata and $P$. marmorata, which were classified as ancillary (occurrence less than 40\%). Among the species, $M$. tuberculata were the highest average density (1,636 ind. $\left.\mathrm{m}^{-2}\right)$ in Serrinha reservoir, showed a strong adaptation to the environmental conditions, due to its high dominance in all the reservoirs, being probably the main cause for the low diversity and density indices of native molluscs. Since $P$. marmorata presented low density and frequency, becoming an important point to be investigated as possible species impaired by the dominance of $M$. tuberculata.

Keywords: benthic community; gastropods; bioinvasion; limnic environments.

Resumo: Objetivo: O objetivo do presente estudo foi realizar um levantamento das espécies de moluscos e avaliar o efeito de espécies exóticas sobre os moluscos nativos de três reservatórios da Bacia do Pajeú - Cachoeira II, Jazigo e Serrinha. Métodos: A amostragem foi realizada com rede de arrasto (abertura de malha de $5 \mathrm{~mm}$ ) e puçá (abertura de malha $2 \mathrm{~mm}$ ). Resultados e conclusóes: Foram quantificados 60.244 exemplares, distribuídos entre as espécies Melanoides tuberculata (49.398), Pomacea lineata (573), Biomphalaria straminea (376) e Physa marmorata (01). A espécie exótica 
invasora $M$. tuberculata foi dominante em todos os reservatórios com abundância relativa superior a $85 \%$, as demais espécies foram classificadas como ocasionais e raras com destaque para Physa marmorata que está presente na lista vermelha de espécies vulneráveis a extinção. Quanto à frequência de ocorrência, todas as espécies foram classificadas como euconstantes (ocorrência superior a 65\%), exceto P. lineata e P. marmorata que foram classificadas como acessórias (ocorrência inferior a 40\%). Dentre as espécies, $M$. tuberculata apresentou a maior densidade média ( $\left.1.636 \mathrm{ind} . \mathrm{m}^{-2}\right)$ no reservatório Serrinha, demonstrando forte adaptação às condiçôes ambientais, devido sua alta dominância em todos os reservatórios, sendo provavelmente a principal causa pelos baixos índices de diversidade e densidade dos moluscos nativos. Uma vez que $P$. marmorata apresentou baixa densidade e frequência, tornando-se um ponto importante a ser investigado como possível espécie prejudicada pela dominância do M. tuberculata.

Palavras-chave: comunidade bentônica; gastrópodes; bioinvasão; ambientes límnicos.

\section{Introduction}

Biologists, ecologists and environmental researchers believe that invasions by exotic species are the main causes of native species extinction (Wilcove et al., 1998; Fritts \& Rodda, 1998). The introduction of exotic species became a key ecological factor, in which invading organisms increasingly alter aquatic communities (Gurevitch \& Padilla, 2004).

The Mollusca phylum comprises over one hundred thousand species, which are found in different environments, such as terrestrial, marine and freshwater. This phylum is represented by the classes Gastropoda and Bivalvia in freshwater environments (Mansur et al., 1987). Brazil has 256 described species of freshwater gastropods and, according to Simone (2006) this number is underestimated compared with the diversity found in other countries. These animals are found in various water habitats such as rivers, weirs, ponds and lakes, living partially or totally buried in the substrate (Mansur et al., 1987) or associated with submerged aquatic macrophytes (Simone, 1999; Santana et al., 2009). According to Simone (1999), a great variability of Mollusks may occur in freshwater environments, however, the occurrence and distribution of this species are related to their adaptation and habitat characteristics.

Freshwater mollusks are among the most endangered group of species, despite their widespread distribution and diversity (Bogan, 2008). The main causes for this species endangerment are related to the high concentrations of agrochemicals in the water, eutrophication, dam constructions and drainage (Allan, 2004). Moreover, the introduction of exotic species has been considered a major impact factor and responsible for the decline of some native species (Mansur et al., 2012). The Mollusca phylum is among the most introduced groups of species (Lucca \& Kamada, 2012). These biological invasions have caused significant and noticeable economic effects, damaging hydroelectric power plants, industries, and modifying benthic communities or indirectly affecting other aquatic communities (Garcia \& Protogino, 2005).

According to Camargo \& Giarrizzo (2009), the mollusks stands out in freshwater environments due to their number of species, biomass and function in trophic chains, since they are primary consumers of and food for many animal groups, especially fish, birds and mammals. Mollusks are important bio-indicators of environmental quality in Brazil (Salánki et al., 2003) and vectors of diseases (Souza et al., 2001; Thiengo et al., 2004), however, few studies have been conducted on the effects of biological invasions.

Most of these studies report invasion of mollusk species, emphasizing the environmental impacts caused to ecosystems and economic and health problems (Fernandez et al., 2003). Most studies in the Brazilian semiarid region are related to their taxonomy, occurrence and systematics. Abílio et al. $(2006,2007)$ and Santana et al. (2009) assessed the composition and abundance of coastal gastropods associated with aquatic macrophytes of the semiarid in the State of Paraíba. Souza \& Abílio (2006) evaluated the taxonomic units of the zoobenthos of two intermittent lakes of the Paraíba semiarid. Santos \& Eskinazi-sant'anna (2010) evaluated the occurrence and abundance of the mollusk Melanoides tuberculata (Muller, 1774) in the Piranhas River Basin of the State of Rio Grande do Norte. However, studies describing the biology and ecology of mollusks found in the continental water bodies of the Brazilian semiarid are still scarce in the literature. Therefore, studying these animals is important to contribute to the information on this species diversity and distribution.

The objective of this work was to survey mollusk species of the Pajeú River Basin, in the semiarid 
region of the State of Pernambuco, Brazil, and to evaluate risks and possible impacts of exotic species on native species, aiming to produce better information on the management, conservation and preservation of the native mollusks.

\section{Material and Methods}

\subsection{Study area}

The study was conducted in the Pajeú River Basin located between the coordinates $07^{\circ} 16^{\prime} 20$ “and $08^{\circ} 56^{\prime} 01^{\prime}$ " south latitude, and 36 $59^{\circ} 00$ "and 38 $57^{\circ} 5^{\prime}$ " west longitude (Pernambuco, 1998). The hydrological basin of Pajeú is fully inserted in the state of Pernambuco (Figure 1) and has an area of $16,685.63 \mathrm{~km}^{2}$, covering 25 municipalities and is characterized by being the largest basin of Pernambuco state (IBGE, 2010).

According to Peel et al. (2007), the dominant climate in region is the semiarid with annual rainfall of less than $431.8 \mathrm{~mm}$ and predominant vegetation of the caatinga type (Freire $\&$ Pacheco, 2011), showing a great hydric deficit, high temperatures, high rates of evaporation, a rainy period between January and June and periods of drought between July and December. Serra Talhada city is located in the semiarid region of the hydrological basin of Pajeú, the large reservoirs, are: Serrinha II $\left(311,000,000 \mathrm{~m}^{3}\right)$, Cachoeira II $\left(21,031,145 \mathrm{~m}^{3}\right)$, Jazigo $\left(15,543,300 \mathrm{~m}^{3}\right)$ and
Saco I $\left(36,000,000 \mathrm{~m}^{3}\right)$, these reservoirs are of great importance to the population around them, mainly due to the fishing potential, irrigation and supply (Nascimento-Filho et al., 2014; Lima \& Shinozaki-Mendes, 2015).

\subsection{Limnological variables}

During the whole study, was measured the monthly average rainfall $(\mathrm{P})$, in millimeters and water temperature (To degrees Celsius) for the period from August 2008 to July 2009 and from May to November 2012 (source: INPE).

\subsection{Field methodology}

The study was held with from monthly daytime collection held in three reservoirs (Cachoeira II e Jazigo - august/2008 to july/2009 and may to November/2012; Serrinha - may to November/2012), reflecting the seasonal periodicity (dry and rainy). Sampling was carried out a trawl net with mesh opening of $5 \mathrm{~mm}$ (width: $1.85 \mathrm{~m} \times$ height: $0.85 \mathrm{~m}$ ) and hand net with aluminum frame, with $60 \mathrm{~cm}$ of diameter and meh opening of $2 \mathrm{~mm}$. Were held with the trawl net tree manual trawled trough a 5 meters area, in transects parallels to margin, in depths varying from $50 \mathrm{~cm}$ to 1.5 meters.

The dip net was utilized to capture the epiphany associed to margin vegetation (one meter of margin distance). The samples were obtained in tree points with depths varying from 20 to $50 \mathrm{~cm}$, with tree

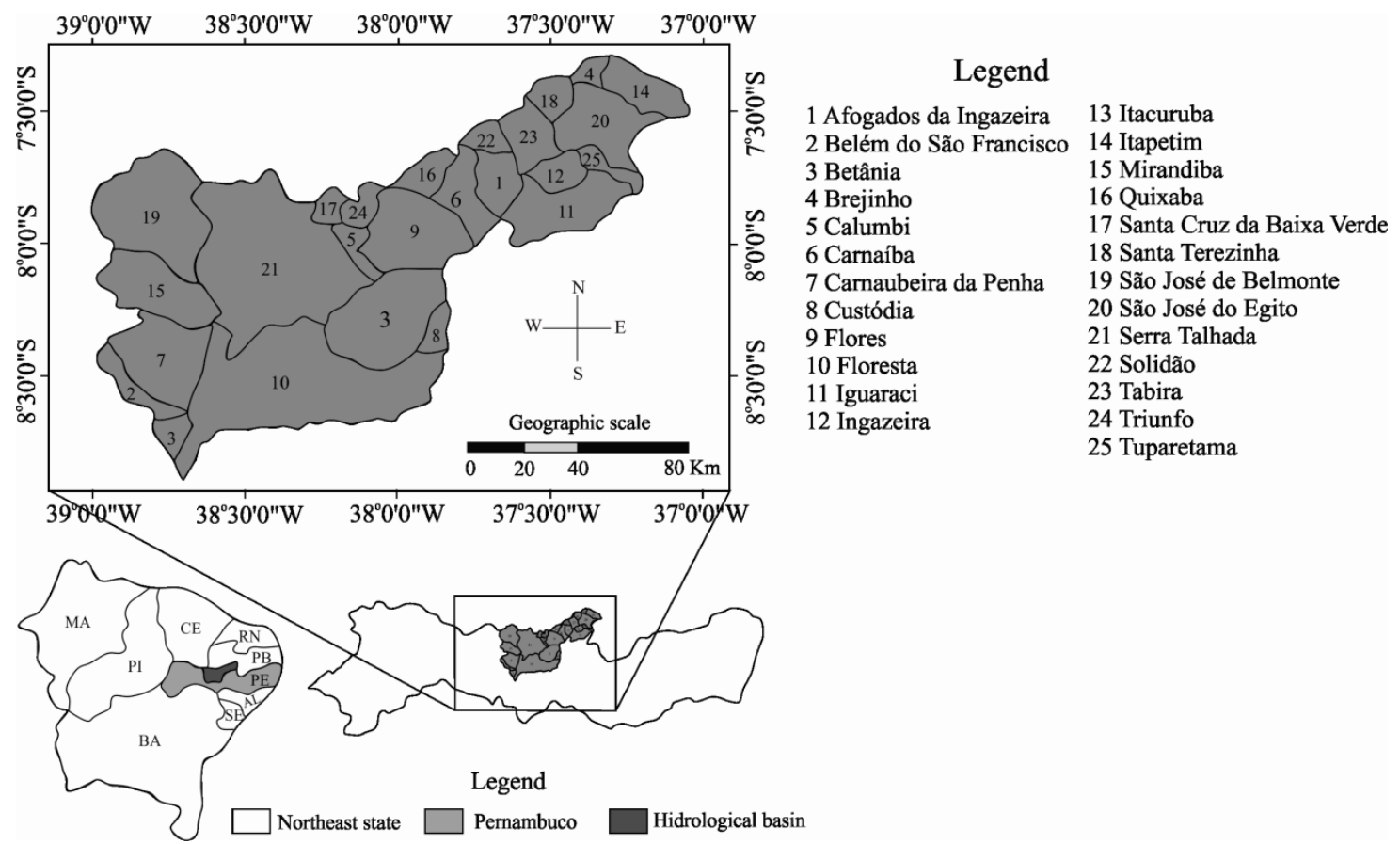

Figure 1. Location of the Pajeú River basin located of Pernambuco state, Brazil. 
repetitions. The collected material was packed in plastic bags labeled and fished with 10\% neutral formalin. In the laboratory, the samples were washed on site through a net with mesh size 2.1, 0.5 and $0.25 \mathrm{~mm}$. Then the material was replaced by $70 \%$ ethanol. Afterwards, the material was identified with the aid of a stereomicroscope and identification bibliography suggested by Simone (2006) and Barbosa (1995).

The data were initially treated in order to verify the distribution of normality of distribution errors and homoscedasticity of variances test Shapiro-Wilk ( $p>0.05)$ (Mendes, 1999). As variances showed non-homogeneous, was use non-parametric test Kruskal-Wallis to verify significant differences in the densities in the dry and rainy period. We calculated the richness of species, relative abundance (\%) proposed by Mccullough \& Jackson (1985), density of individuals per square meter (ind. $\mathrm{m}^{-2}$ ), frequency of occurrence (\%), Jablonska \& Paturej (1999), diversity of Shannon-Wiener ( $\left.\mathrm{H}^{\prime}\right)$ and equitability (J'). For equitability the months with zero or only one species were disregarded. We checked the similarity of the molluscs distribution among the different reservoirs of the region, a cluster analysis using Bray-Curtis distance. We use Spearman's correlation to check possible relation between temperature, rainfall and density species.

\section{Results}

Over the sample period were quantified a total of 60,244 individuals, all belonging to Gastropoda class, distributed among species Melanoides tuberculata (Muller, 1774) located in Thiaridae family, Neotaenioglossa order and Pomacea lineata (Spix, 1827) belonging to Ampullariidae family, Architaenioglossa order, Biomphalaria straminea (Say, 1818), located at Planorbidae family, order Pulmonata and Physa marmorata Guilding, 1828, included in Physidae family.

In Cachoeira II reservoir (August/2008 to July/2009), were collected 3,857 individuals, distributed among the species $M$. tuberculata (3,662 specimens), P. lineata (195 specimens). $M$. tuberculata being the dominant species with relative abundance greater than $90 \%$. As for the frequency of occurrence, both species present constants. In Jazigo reservoir same period, were collected 4,968 individuals, distributed among the species $M$. tuberculata (4,408 specimens), B. straminea (376 specimens), P. lineata (184 specimens). M. tuberculata showed higher relative abundance $85 \%$, while the other two species showed relative abundance of 7.57 and $3.70 \%$, respectively. Despite the dominance of $M$. tuberculata all described species were detected during the study occurred with a frequency of $80 \%$. The gastropod showed dominance in the two aforementioned reservoirs (relative abundance greater than 85\%). Simultaneously, despite the large occurrence of Thiaridae over the months, all species were constant throughout the sampling period (frequency of occurrence greater than 66\%).

In the same reservoir between the months of May to November/2012, was collected 2,569 individuals, represented by the species M. tuberculata $(2,565)$ specimens, P. lineata (3) and $P$. marmorata only (1) specimen. $M$. tuberculata was dominant (relative abundance greater than 90\%) and constant (frequency of occurrence than $80 \%$ ) during the study, while the remaining species were classified as occasional (less than $10 \%$ occurrence). Study conducted Serrinha reservoir, in the same period were observed a total abundance of 49,589 specimens, represented by the species M. tuberculata $(49,398)$ and P. lineata (191) specimens. $M$. tuberculata was dominant (relative abundance greater than 90\%) and P. lineata rare (less than 10\%). M. tuberculata showed constant throughout the study (above 80\%) and P. lineata frequent $(75 \%$ frequency of occurrence) (Table 1$)$.

In Cachoeira II reservoir maximum density values were observed in the months of December/2008, January and February/2009, mainly represented by $M$. tuberculata 105.94 ind. $\mathrm{m}^{-2}, 102.13$ and 118.49 ind. $\mathrm{m}^{-2}$, respectively (Figure 2-1A). In Jazigo reservoir highest densities of mollusks were observed between the months of November/2008 to February/2009, with an average of 88.97 ind. $\mathrm{m}^{-2}$ (Figure 2-1B). Over that sample period the highest densities were observed for invasive $M$. tuberculata, with higher values 85.51 ind. $\mathrm{m}^{-2}$ individuals. Between May to November/2012 the same reservoir maximum density values were observed in the months of June and October/2012, with 87.66 and 62.08 ind. $\mathrm{m}^{-2}$. Represented mostly by M. tuberculata 87.16 and 62.08 ind. $\mathrm{m}^{-2}$, respectively (Figure 2-1C). In Serrinha reservoir the highest densities were observed in May 1,856 ind. $\mathrm{m}^{-2}$ and June 1,431 ind. $\mathrm{m}^{-2}$, represented in most of the gastropod $M$. tuberculata with 1,845 and 1,427 ind. $\mathrm{m}^{-2}$, respectively (Figure 2-1D).

In Cachoeira II and Jazigo reservoirs between (August/2008 to July/2009) the equitability (J) maximum values were observed (1) in the months 
Table 1. Relative abundance and frequency of occurrence for Gastropoda species collected in three reservoirs in the Pajeú River basin between 2008 and 2009 and 2012.

\begin{tabular}{|c|c|c|c|c|c|}
\hline \multicolumn{6}{|c|}{ Relative Abundance (\%) } \\
\hline \multirow{2}{*}{$\begin{array}{c}\text { Reservoirs } \\
\text { Melanoides tuberculata }\end{array}$} & \multirow{2}{*}{$\begin{array}{c}\begin{array}{c}\text { Cachoeira } \\
\text { (2008/09) }\end{array} \\
91.80\end{array}$} & \multicolumn{2}{|c|}{$\begin{array}{c}\text { Jazigo } \\
(2008 / 09)(2012) \\
\end{array}$} & \multirow{2}{*}{$\begin{array}{c}\begin{array}{c}\text { Serrinha } \\
\text { (2012) }\end{array} \\
99.53\end{array}$} & \multirow{2}{*}{$\begin{array}{c}\text { Classification } \\
\text { Dominant }\end{array}$} \\
\hline & & 87.14 & 99.84 & & \\
\hline Biomphalaria straminea & - & 7.76 & - & - & Occasional \\
\hline Pomacea lineata & 8.20 & 2.98 & 0.1 & 0.37 & $\begin{array}{l}\text { Occasional/ } \\
\text { Rare }\end{array}$ \\
\hline Physa marmorata & - & - & 0.05 & - & Rare \\
\hline \multicolumn{6}{|c|}{ Occurrence Abundance (\%) } \\
\hline Melanoides tuberculata & 66.7 & 100 & 100 & 100 & Euconstant \\
\hline Biomphalaria straminea & - & 77.30 & - & - & Euconstant \\
\hline Pomacea lineata & 66.7 & 81.8 & 25 & 75 & $\begin{array}{l}\text { Euconstant } \\
\text { and Acessory }\end{array}$ \\
\hline Physa marmorata & - & - & 25 & - & Acessory \\
\hline
\end{tabular}
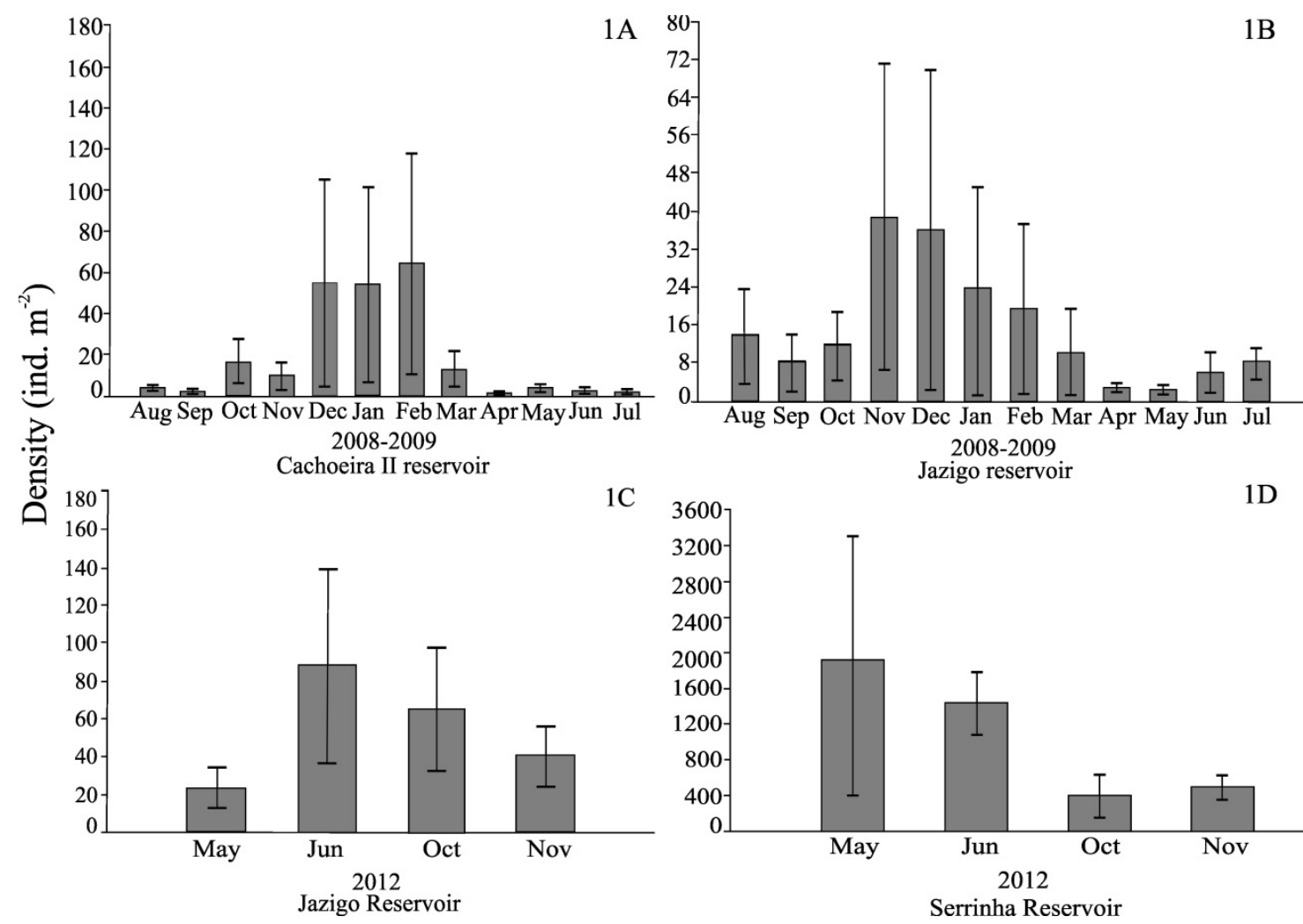

Figure 2. Mean values of density (ind. $\mathrm{m}^{-2}$ ) in Cachoeira II and Jazigo/2008-2009 (1A and 1B), Jazigo/2012 (1C) and Serrinha/2012 (1D) reservoirs, located in Pajeú river basin, Serra Talhada, Brazil.

August and September and minimum 0.04 in October. Shannon diversity $\left(\mathrm{H}^{\prime}\right)$ showed maximum value 0.69 nats.ind $^{-1}$ in the months from August to September and minimum value 0.03 nats.ind ${ }^{-1}$ in October/2008. In Jazigo reservoir presented maximum value (0.86) in April and minimum value (0.17) in December, with 0.96 nats.ind ${ }^{-1}$ maximum $\left(\mathrm{H}^{\prime}\right)$ in April and minimum 0.13 nats.ind ${ }^{-1}$ in January and February (Figure 3). In the same reservoir between May to Nov/12, the (J) ranged from zero to
0.02 in the months of May and October/2012. (H') ranged zero and 0.014 nats.ind $^{-1}$, with higher values in the months of June and November. Same period the Serrinha reservoir presented the $(\mathrm{J})$ ranged from 0.001 to 0.05 and a ( $\left.\mathrm{H}^{\prime}\right)$ with representation from 0.001 to 0.035 nats.ind $^{-1}$ (Figure 4).

In Figure 5, the dendrogram of the application of the Bray-Curtis index is presented. Note that distinct groups were formed, where the greatest similarity was obtained between the Cachoeira II 


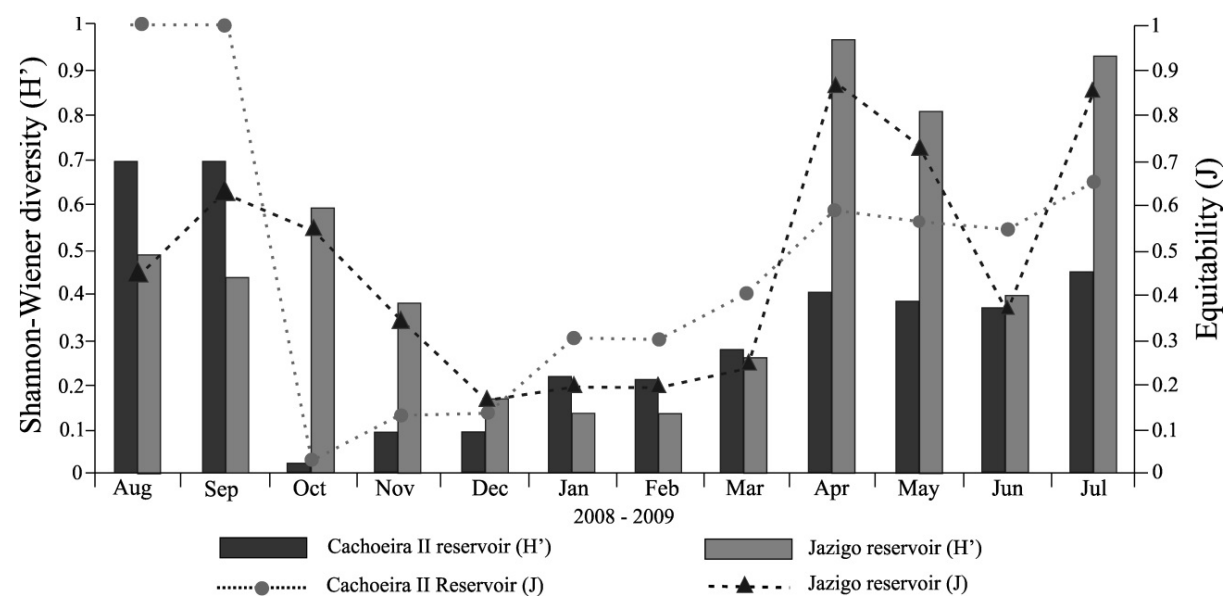

Figure 3. Shannon-Wiener's diversity $\left(\mathrm{H}^{\prime}\right)$ nats.ind ${ }^{-1}$ and equitability $(\mathrm{J})$ for the mollusks sampled of Cachoeira II and Jazigo reservoirs in year 2008 and 2009, Serra Talhada, Brazil.

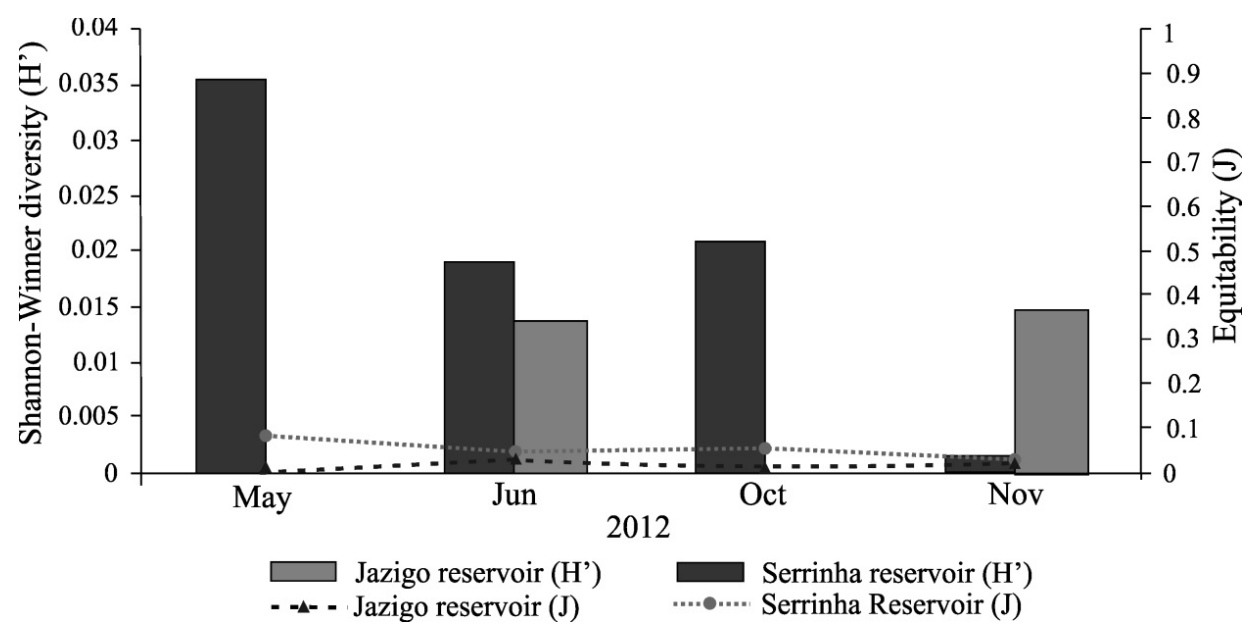

Figure 4. Shannon-Wiener's diversity $\left(\mathrm{H}^{\prime}\right)$ nats.ind ${ }^{-1}$ and equitability $(\mathrm{J})$ for the mollusks sampled Serrinha and Jazigo reservoirs in year 2012, Serra Talhada, Brazil.

\section{Jazigo/12 Jazigo (08/09) Serrinha/12 Cachoeira II (08/09)}

0.99
0.96
0.93
$0.90-$
0.87
0.84
0.81
$0.78-$
0.75

Figure 5. Dendrogram similarity of mollusks in continental water bodies of Pernambuco semiarid, using Similarity index Bray-Curtis's. 
and Serrinha reservoirs (> 99\%). The Jazigo reservoir $2008 / 2009$ formed a group with previous reservoirs (80\%) of similarity. The Jazigo reservoir/2012 was connected to the other reservoirs with similarity equal to $75 \%$.

There was no significant influence of rainfall and water temperature in relation to the abundance and distribution of the species (Jazigo reservoir, $\mathrm{p}=0.991$ and Cachoeira II reservoir in 2008/2009, $\mathrm{p}=0.241$; Serrinha reservoir in 2012, $\mathrm{p}=0.08$ ).

\section{Discussion}

Freshwater mollusks are represented by the classes Gastropoda and Bivalvia, with 305 species known in Brazil, 115 from the Bivalvia and 193 from the Gastropoda class (Avelar, 1999). Only mollusks form the Gastropoda class were sampled for the present study, with the Melanoides tuberculata (Thiaridae) as the first and Pomacea lineata (Ampullariidae) as the second most representative species of this class. A study carried out in a semiarid seasonal lake by Abílio et al. (2007) presented P. lineata among the five most found species, confirming the results of the present study.

The species Biomphalaria straminea (Planorbidae) and Physa marmorata (Physidae) were little represented, with low abundance compared with the exotic mollusk $M$. tuberculata. The greater abundance of this species is due to its capacity to explore different environments and tolerance to limnological variation and different types of substrates (Freitas et al., 1987). A low biodiversity of mollusks was found in the studied reservoirs, probably due to the presence of the exotic mollusk species M. tuberculata. According to Allan \& Flecker (1993), the dispersion of exotic species is the second major cause of loss of aquatic biodiversity. The exotic species $M$. tuberculata has spread in Brazil in the last decades, from the South to the North and Northeast regions, with more than 60 occurrences reported in the country (Fernandez et al., 2003).

The competition between the M. tuberculata and the native mollusks is widely reported in the literature (Pointier \& Augustin, 1999). Many studies in Brazil indicated that native populations of Aylacostoma (Reeve, 1860) have been replaced by $M$. tuberculata populations (Fernandez et al., 2003). M. tuberculata was the most abundant and frequently found species in the reservoirs during the study, as expected. The $M$. tuberculata growth, reproductive rates, tolerances and food preferences (Rader et al., 2003; Coat et al., 2009) may explain its ability to colonize and dominate clusters of freshwater mollusks in tropical and subtropical regions (Pointier et al., 1994; El-Kady et al., 2000; Guimarães et al., 2001).

According to Lima et al. (2013), this species is a great competitor and has successfully reduced populations of species of the genus Biomphalaria, which are intermediate hosts of schistosomiasis. However, species of the family Thiaridae has caused significant effects on native mollusks (Pointier \& Augustin, 1999; Guimarães et al., 2001; Giovanelli et al., 2003, 2005). The small number of individuals of Pomacea lineata and Biomphalaria straminea, which presented densities below 100 ind. $\mathrm{m}^{-2}$, intensifies the effect of the exotic species $M$. tuberculata, reducing the native populations in the reservoirs.

The information shown in the present study clearly denote the efficiency of this species in colonizing artificial reservoirs in the semiarid region of the Pajeú River Basin, presenting high density (1.856 ind. $\mathrm{m}^{-2}$ ) compared with the estimated population densities found worldwide (100 to 13.400 ind. $\mathrm{m}^{-2}$ ) (Lévèque, 1971; Pointier et al., 1989). However, the large amount of empty shells and the size of the individuals suggest that their population have been controlled by some events, which are forms of control to be investigated to control this exotic species.

The abundance of species had no significant correlation with the rainfall and temperature of the water, however, the months without rainfalls and higher temperatures presented greater amounts of individuals. The number of individuals increases in the dry season, probably because of the increased availability of food, such as plant residues, during the dry season in arid and semiarid regions, making the environment to support a higher density of individuals (Extence, 1981). The results found contribute to the understanding of the snails of continental water bodies, provide bases for future researches and can be used as a source of information in the case of native species become extinct over the years due to the proliferation of $M$. tuberculata, as well as for researches related to evolution of species. The development of researches, monitoring the aquatic ecosystems of the Caatinga biome, is important, in order to understand their structure and functioning regarding the benthic fauna, since these ecosystems can be used as bioindicators of environmental quality, and are important to public health.

The exotic species $M$. tuberculata was the most frequent and abundant in all the studied 
reservoirs probably adapt well the variations of abiotic local factors and also the lack of a natural predator. The results may reflect that effect on native populations Biomphalaria straminea and Physa marmorata, the latter, there is to be vulnerable species extinction.

\section{References}

ABÍLIO, F.J.P., FONSECA-GESSNER, A.A., MILK, R.M. and RUFFO, T.L.M. Gastropods and other invertebrates benthic sediment and associated with Eichhornia crassipes of a hypertrophic reservoir of the semiarid Paraiba. Magazine of Biology and Earth Sciences, 2006, 6(1), 165-178.

ABÍLIO, F.J.P., RUFFO, T.L.M., SOUZA, A.H.F.F., FLORENTINO, H.S., OLIVEIRA JUNIOR, E.T., MEIRELES, B.N. and SANTANA, A.C.D. Benthic macroinvertebrates as bioindicators of environmental quality of caatinga aquatic bodies. Oecologia Brasiliensis, 2007, 11(3), 397-409.

ALLAN, J.D. and FLECKER, A.S. Biodiversity conservation in running waters. Identifying the major factors that threaten destruction of reverine species and ecosystems. Biology Science, 1993, 43(1), 32-43.

ALLAN, J.D. Landscapes and Riverscapes: the influence of land use on stream ecosystems. Annual Review of Ecology, Systematics and Evololution, 2004, 35, 257 284. http://dx.doi.org/10.1146/annurev.ecolsys.

AVELAR, W.E.P. Bivalve molluscs. In: C.A. JOLY and C.E.M. BICUDO, orgs. Biodiversity of the State of São Paulo, Brazil: synthesis of knowledge at the end of the year. São Paulo: FAPESP, 1999, pp. 65-68. Invertebrates of Fresh Water, vol. 4.

BARBOSA, F.S. Topics in medical malacological. São Paulo: Editora Fiocruz, 1995.

BOGAN, A. Global diversity of freshwater mussels (Mollusca, Bivalvia) in freshwater. Hydrobiologia, 2008, 595(1), 139-147. http: //dx.doi.Org /10.1007/ s1075000790117.

CAMARGO, M. and GIARRIZZO, T. Biological parameters. In: M. CAMARGO and R. GHILARDI JUNIOR, eds. Entre a terra, as águas, e os pescadores do médio Rio Xingu: uma abordagem ecológica. Belém: Eletronorte, 2009, pp. 215-231.

COAT, S., MONTI, D., BOUCHON, C. and LEPOINT, G. Trophic relationships in a tropical stream food web assessed by stable isotope analysis. Freshwater Biology, 2009, 54(5), 10281041. http:// dx.doi.org/10.1111/j.1365-2427.2008.02149.x.

ELKADY, G., SHOUKRY, A., REDA, L. and ELBADRI, Y. Survey and population dynamics of freshwater snails in newly settled areas of the Sinai Peninsula. Egyptian Journal of Biology, 2000, 2(1), 42-48.
EXTENCE, C.A. The effect of drought on benthic invertebrate communities in a lowland river. Hydrobiologia, 1981, 83(2), 217-224. http://dx.doi. org/10.1007/BF00008269.

FERNANDEZ, M.A., THIENGO, S.C. and SIMONE, L.R. Distribution of the Introduced freshwater snail Melanoides tuberculatus (Gastropoda: Thiaridae) in Brazil. The Nautilus, 2003, 117(3), 78-82.

FREIRE, N.C.F. and PACHÊCO, A.P. Desertification: analysis and mapping. Recife: Universidade Federal de Pernambuco, 2011.

FREITAS, J.R., BEDÊ, L.C., DE MARCO, P., ROCHA, L.A. and SANTOS, M.B.L. Population dynamics of aquatic snails in Pampulha Reservoir. Memories of the Oswaldo Cruz Institute, 1987, 96(1), 123-125.

FRITTS, T.H. and RODDA, G.H. The role of introduced species in the degradation of island ecosystems: a case history of Guam. Annual review of Systematics and Ecology, 1998, 29, 113-140.

GARCIA, M.L. and PROTOGINO, L.C. Invasive freshwater mollusks are consumed by natives fishes in South America. Journal of Applied Ichthyology, 2005, 21(1), 34-48. http://dx.doi.org/10.1111/j.14390426.2004.00570.x.

GIOVANELLI, A., SILVA, C.L.P.A.C., LEAL, G.B.E. and BAPTISTA, D.F. Habitat preference of freshwater snails in relation to environmental factors and the presence of the competitor snail Melanoides tuberculatus (Müller, 1774). Memories of the Oswaldo Cruz Institute, 2005, 100(2), 169-176.

GIOVANELli, A., VIEIRA, M.V. and SILVA, C.L.P.A.C. Apparent competition through facilitation between Melanoide stuberculata and Biomphalaria glabrata and the control of schistosomiasis. Memories of the Oswaldo Cruz Institute, 2003, 98(3), 429-431.

GUIMARÃES, C., SOUZA, C. and SOARES, D. Possible competitive displacement of planorbids by Melanoides tuberculata in Minas Gerais, Brazil. Memórias do Instituto Oswaldo Cruz, 2001, 96, 173-176. http://dx.doi.org/10.1590/S007402762001000900027.

GUREVITCH, J. and PADILLA, D.K. Are invasive species a major cause of extinctions? Trends in Ecology \& Evolution, 2004, 19(9), 470-474. http://dx.doi. org/10.1016/j.tree.2004.07.005. PMid:16701309.

INSTITUTO BRASILEIRO DE GEOGRAFIA E ESTATÍSTICA - IBGE. Demographic census 2010 [online] 2010 [viewed 1 Aug. 2015]. Available from: http://www.ibge.gov.br/

JABLONSKA, I. and PATUREJ, E. The domination and constancy of occurence of invertebrate communities in the Hancznska Bay, Lake Wigry, NW Poland. Acta Hydrobiologica, 1999, 41(6), 249-253. 
LÉVÈQUE, C. Equation de Von Bertalanff yet croissance des mollusques benthiques du lac Tchad. Cahiers ORSTOM. Hydrobiologie, 1971, 5(3), 263-283.

LIMA, J.R.C. and SHINOZAKI-MENDES, R.A. Abiotic profile and viability to aquaculture in Saco, Pajeú, Pernambuco. Journal of Agricultural Sciences, 2015, 10(1), 153-158.

LIMA, L.F.O., BRASIL, B.I.A.L. and MARTINSSILVA, M.J. Melanoides tuberculata (Müller, 1774): Northeastern dispersal in the São Francisco basin, Brazil. Check List, 2013, 9(1), 162-164. http://dx.doi. org/10.15560/9.1.162.

LUCCA, G.M. and KAMADA, C.D.M. Occurred Corbicula fluminea and Melanoides tuberculata (exotic clams) in the stream Retreat Homesick, Ribeirão Preto SP. Environmental Forum Alta Paulista, 2012, 8(2), 338-347.

MANSUR, M.C.D., SANTOS, C.P., PEREIRA, D., PAZ, I.C.P., ZURITA, M.L.L., RODRIGUEZ, M.T.R., NEHRKE, M.V. and BERGONCI, P.E.A. Limnological mollusks in Brazil: biology, prevention and control. Porto Alegre: Redes Editora Ltda, 2012, 418 p.

MANSUR, M.C.D., SCHULZ, C. and GARCES, L.M.M.P. Freshwater bivalve molluscs: identification of the genera of southern and eastern Brazil. Biological Acta Leopoldina, 1987, 2, 181-202.

MCCULLOUGH, J.D. and JACKSON, D.W. Composition and productivity of the benthic macroinvertebrate community of a subtropical reservoir. Hydrobioly, 1985, 70, 221-235.

MENDES, P.P. Statistics applied to aquaculture. Recife: Ed. Bargaço, 1999, 265 p.

NASCIMENTO-FILHO, S.L., VIANA, G.F.S. and GOMES, R.L.M. Inventory of the limestone mollusks of three large reservoirs inthe backlands of Pernambuco, Brazil. Scintia Plena, 2014, 10(11), 1-7.

PEEL, M.C., FINLAYSON, B.L. and MCMAHON, T.A. Updated world map of the Köppen-geiger climate classification. Hidrological Earth System Science, 2007, 11(5), 1633-1644. http://dx.doi. org/10.5194/hess-11-1633-2007.

PERNAMBUCO. Secretaria de Ciência, Tecnologia e Meio Ambiente de Pernambuco - SECTMA. Plano Estadual de Recursos Hidricos - Pernambuco. Recife: SECTMA-PE, 1998, 223 p., vol. 1.

POINTIER, J., INCANI, R., BALZAN, C., CHROSCIECHOWSKI, P. and PRYPCHAN, S. Invasion of the rivers of the central littoral region of Venezuela by Thiara granifera and Melanoides tuberculata (Mollusca: Prosobranchia: Thiaridae) and the absence of Biomphalaria glabrata snail host of Schistosoma mansoni. The Nautilus, 1994, 107(4), 124-128.

POINTIER, J.P. and AUGUSTIN, D. Biological control and invading freshwater snails: a case study. Comptes
Rendus de l'Académie des Sciences-Series III-Sciences de la Vie, 1999, 322(12), 1093-1098.

POINTIER, J.P., GUYAR, A. and MOSSER, A. Biological control of Biomphalaria glabrata and B. straminea by the competitor snail Melanoides tuberculata in the transmission site of schistosomiasis in Martinique, French West Indies. Annals of Tropical Medicine and Parasitology, 1989, 83, 263-269. http:// dx.doi.org/10.1080/00034983.1989.11812342. PMid:2513787.

RADER, R, BELK, $M$ and KELEHER, M. The introduction of an invase snail Melanoides tuberculata to spring ecosystems of the Bonneville Basin, Utah. Freshwater Journal of Ecology, 2003, 18(4), $647-$ 657. http://dx.doi.org/10.1080/02705060.2003.9 664007.

SALÁNKI, J., FARKAS, A., KAMARDINA, T. and RÓZSA, K.S. Molluscs in biological monitoring of water quality. Toxicology Letters, 2003, 140, 403-410. http://dx.doi.org/10.1016/S0378-4274(03)00036-5. PMid:12676488.

SANTANA, A.C.D., SOUZA, A.H.F.F., RIBEIRO, L.L. and ABÍLIO, F.J.P. Macroinvertebrates associated with the aquatic marina Cobras L. Avelós stream, in the semiarid region of Brazil. Journal of Biology and Earth Sciences, 2009, 9(2), 116.

SANTOS, C.M. and ESKINAZI-SANT'ANNA, E.M. The introduced snail Melanoides tuberculatus (Muller, 1774) (Mollusca: Thiaridade) in aquatic ecosystems of the Brazilian Semiarid Northeast (Piranhas-Assu River basin, State of Rio Grande do Norte). Brazilian Journal of Biology = Revista Brasileira de Biologia, 2010, 70(1), 1-7. http://dx.doi.org/10.1590/S151969842010000100003.

SIMONE, L.R.L. Land and freshwater molluscs of Brazil. São Paulo: FAPESP, 2006.

SIMONE, L.R.L. Molluscs Gastropods. In: D. ISMAEL, W.C. VALENTI, T. MATSUMURA TUNDISI and O. ROCHA, eds. Freshwater invertebrates. São Paulo: FAPESP, 1999, 176 p. vol. 4: Biodiversity of the State of São Paulo, Brazil: synthesis of knowledge at the end of Century.

SOUZA, A.H.F.F. and ABÍLIO, F.J.P. Zoobentos of two intermittent lagoons of the Paraíba caatinga and the hydrological cycle. Journal of Biology and Earth Sciences, 2006, 6(1), 146-164.

SOUZA, C.P., CALDEIRA, R.L., DRUMMOND, S.C., MELO, A.L., GUIMARÃES, C.T., SOARES, D.M. and CARVALHO, T.H.E. Geografical distribution of Biomphalaria snails in the state of Minas Gerais, Brazil. Memorias do Instituto Oswaldo Cruz, 2001, 96(3), 293-302. http://dx.doi.org/10.1590/S007402762001000300003 . PMid:11313634.

THIENGO, S.C., MATTOS, A.C., BOAVENTURA, M.F., LOUREIRO, M.S., SANTOS, S.B. and FERNANDEZ, M.A. Freshwater snails and 
Schistosomiasis mansoni in the State of Rio de Janeiro, Brazil: V Norte Fluminense Mesoregion. Memoirs Oswaldo Cruz Institute, 2004, 99(5), 99-103. Supplement 1. http://dx.doi.org/10.1590/S007402762004000900018 . PMid:15486644.

WILCOVE, D.S., ROTHSTEIN, D., DUBOW, J., PHILliPS, A. and LOSOS, E. Quantifying threats to imperiled species in the United States. Bioscience, 1998, 48(8), 607-615. http://dx.doi. org/10.2307/1313420.

Received: 08 December 2016 Accepted: 14 August 2017 